\title{
Benefits of closed area protection for a population of scallops
}

\author{
Bryce D. Beukers-Stewart*, Belinda J. Vause, Matthew W. J. Mosley, \\ Helen L. Rossetti, Andrew R. Brand
}

Port Erin Marine Laboratory, University of Liverpool, Port Erin, Isle of Man IM9 6JA, British Isles

\begin{abstract}
Despite the current interest in using closed areas for fisheries management, few studies have actually examined the benefits for invertebrate fisheries such as scallops. This study details the dynamics of a population of great scallops Pecten maximus (L.), within a closed area and an adjacent fished area off the Isle of Man, over a 14 yr period (1989 to 2003). Scallop densities were very low in both areas when the closed area was set up, but increased at an accelerated rate over time within the closed area. Scallop densities also increased on the adjacent fishing ground, but not to the same extent. Consequently, the density of scallops above the minimum legal landing size (110 mm SL) was more than 7 times higher in the closed area than in the fished area by 2003. There was also a shift towards much older and larger scallops in the closed area and, correspondingly, lower estimates of total mortality. Experimental dredging of 2 plots within the closed area confirmed that fishing drove these differences in population dynamics and structure. These patterns of scallop density, age and size structure resulted in the exploitable biomass (adductor muscle and gonad) of scallops being nearly 11 times higher in the closed area than in the fished area by 2003, and the reproductive biomass was 12.5 times higher. This is significant for fisheries management because the build up of high densities of large $P$. maximus individuals enhanced local reproductive potential and therefore the likelihood of export of larvae to the surrounding fishing grounds. Along with these direct benefits of closed area protection, juvenile scallops had higher survival and individual growth rates in the closed area, apparently in response to reduced fishing disturbance. Although juvenile scallops are not subject to direct removal by fishing, protection during this critical phase therefore appeared to assist the recovery of the closed area population. In summary, this study joins a growing number indicating that the use of closed areas offers a range of benefits over more traditional methods of managing fisheries. Fisheries for relatively sedentary and long-lived species such as P. maximus appear to be particularly suitable for this type of management.
\end{abstract}

KEY WORDS: Closed areas · Marine reserves · Fisheries management · Fishing effects · Larval export · Pecten maximus

Resale or republication not permitted without written consent of the publisher

\section{INTRODUCTION}

Research into the use of closed areas for fisheries management has increased at an almost exponential rate over the last decade as traditional management methods continue to fail (Mosquera et al. 2000, Pauly et al. 2002). This interest is due to a range of perceived benefits offered by closed area management for both target species and the environment. Perhaps not surprisingly, numerous studies have now shown that closed area protection can increase the abundance and mean size of target species (Mosquera et al. 2000, Halpern \& Warner 2002, Halpern 2003). This is thought to enhance local reproductive output and therefore lead to export of larvae to surrounding areas that are open to fishing (Roberts et al. 2001, Gaines et al. 2003, Gell \& Roberts 2003, Grantham et al. 2003). For mobile species, there can also be spillover of juveniles/adults to adjacent areas through emigration or densitydependent dispersal (Lizaso et al. 2000, McClanahan \& 
Mangi 2000, Gell \& Roberts 2003). Even in fisheries with minimum size limits, protection of juveniles from fishing disturbance may improve both survival and growth during this critical life-history phase (Myers et al. 2000).

Closed area protection of marine habitats and nontarget species has also been shown to help maintain or increase biodiversity, particularly in areas subject to bottom-disturbing fishing practices such as trawling or dredging (Allison et al. 1998, Dayton et al. 2000, Bradshaw et al. 2001, Thrush \& Dayton 2002, Halpern 2003). Maintaining more complete ecosystems in closed areas may also provide benefits that flow back to the species targeted by fisheries (Jennings \& Kaiser 1998). For example, hydroids and bryozoans are key settlement habitats for scallop larvae but are among the first species removed by fishing disturbance (Bradshaw et al. 2001, 2003). Lowering fishing disturbance may also reduce turbidity and improve water quality, which for filter-feeding invertebrates such as many shellfish species may have implications for survival and growth (Brand 1991). Finally, maintaining large enough pockets of the marine environment in a relatively undisturbed condition not only provides a safeguard for the future, but also a reference point for examining the effect of fishing on exploited populations and communities (Murray et al. 1999, Dayton et al. 2000).

Fisheries for scallops (Pectinidae) would appear to be ideal candidates for closed area management. Most scallop species are relatively sedentary and have predictable patterns of distribution (Brand 1991). This means that the entire post-settlement life cycle of individuals can generally be protected in the same areaas long as it is large enough to encompass normal movements. Scallops also rely on external fertilisation for reproduction and therefore fertilisation success would benefit greatly from the build up of high adult densities (Peterson \& Summerson 1992, Claereboudt 1999, Marelli et al. 1999). In addition, scallops are broadcast spawners, often with long-lived larvae (20 to 40 d) (Brand 1991) and there would be a high potential for export of larvae from closed areas (Grantham et al. 2003). Finally, scallop fisheries are often characterised by widely fluctuating recruitment levels (up to 60-fold; Wolff 1987) and have consequently proved difficult to manage using traditional methods (Orensanz et al. 1991).

Despite this apparent suitability, there are relatively few published studies on the benefits of closed areas for scallop populations. The best documented example of this is from the Georges Bank fishing grounds off the NE coast of the USA (Murawski et al. 2000, Myers et al. 2000, Stokesbury 2002, Hart 2003, Stokesbury et al. 2004). Three large areas on these grounds were closed to fishing in 1994 and after 4 yr of protection the sea scallop Placopecten magellanicus biomass (total and harvestable) was 9 and 14 times higher, respectively, in the closed than in the open areas (Murawski et al. 2000). Undersize scallops (<82 mm shell height) were also approximately twice as abundant in the closed areas, possibly due to a reduction in indirect fishing mortality. Effective enforcement of the closed areas, based on satellite tracking of fishing boats, was seen as a key factor in the rapid recovery of scallop populations in these protected areas (Murawski et al. 2000).

Modelling studies of this population (Myers et al. 2000, Hart 2003) have examined the fisheries' benefits of opening and closing areas of the Georges Bank on a rotational basis. Both studies predicted higher yieldper-recruit and spawning stock biomass under a rotational scheme than could be achieved using traditional methods aimed at directly controlling fishing mortality. Myers et al. (2000), in particular, advocated the benefits of using closed area management to reduce the effects of indirect fishing mortality on fishery yields. Hart (2003) also suggested that increased egg production and fertilisation from scallops within the areas closed to fishing would lead to higher larval production and hence recruitment to the fished areas. This raises the possibility that keeping some areas permanently closed to fishing may also be an effective management strategy.

In contrast to the studies on Georges Bank, surveys in the San Juan Islands, USA, revealed no difference between marine reserves and unprotected areas for 3 species of scallops (Chlamys rubida, Chlamys behringiana and Hinnites giganteus), even after $8 \mathrm{yr}$ of protection (Tuya et al. 2000). They proposed a number of possible explanations, including poor larval supply to the marine reserves, inadequate sampling methods and a lack of effective enforcement of the closed areas.

Finally, Bradshaw et al. (2001) found substantial increases in the density of the great scallop Pecten maximus after $11 \mathrm{yr}$ of protection in a closed area off the Isle of Man. In addition, they found the mean age of scallops above the minimum legal landing size (MLLS $110 \mathrm{~mm}$ shell length) to be higher inside the closed area (6.5 yr) compared to outside (5.3 yr). These intriguing patterns stimulated us to undertake a new, more comprehensive study at this site, to determine with confidence whether these and other effects of the closed area were repeatable and real.

Our new study extends the work of Bradshaw et al. (2001) by continuing their data collection programme as well as taking a number of new approaches. The key differences have been the modification of their dive survey technique and the collection of scallops during these surveys, both inside and outside the closed area. The new survey method at least partly compensates for the spatial variability of the system 
and shows statistically significant differences between the 2 scallop populations for the first time. Collection of scallops allows comparisons of age and size structure between the 2 populations as well as biomass (exploitable and reproductive). It also allows commercially undersized and legal-sized scallops to be analysed separately, providing comparisons of the mortality and growth rate of undersized scallops in the 2 areas. The results of this new study are discussed in the context of the benefits that closing areas may offer the scallop populations around the Isle of Man and in general. These include the potential for larval export from closed areas, reduced indirect fishing effects (i.e. mortality and damage to undersized scallops caused by fishing disturbance) and the merits of permanent versus rotational closed area management.

\section{MATERIALS AND METHODS}

Study area and species. We studied the Bradda Inshore fishing ground, located off the SW coast of the Isle of Man in the Irish Sea (Fig. 1). Within this fishing ground, an exclusion zone of nearly $2 \mathrm{~km}^{2}$ was established by an Isle of Man government bye-law in March 1989. Fishing with mobile gear such as dredges or trawls was banned within this zone, but fishing with static gear such as lobster or crab pots (which do not capture scallops) was allowed to continue. Maximum water depth within the area is approximately $40 \mathrm{~m}$ and the substrate is a mixture of fine gravel, sand and mud. The closed area was originally intended for research into scallop cultivation and stock enhancement. This was done on a very small experimental scale but was largely unsuccessful and did not contribute significantly to scallop populations in the area (Wilson 1994, Wilson \& Brand 1994). Subsequently, the existence of the closed area has enabled monitoring of the benthic community and scallop population under reduced fishing pressure (Bradshaw et al. 2001).

We focused on the great scallop, Pecten maximus, which supports the most important commercial fishery around the Isle of Man (first sale value of £1.5 million in 2002) (Brand et al. 2004). P. maximus grows relatively quickly in Manx waters, attaining the MLLS of $110 \mathrm{~mm}$ SL in 3 to 5 yr (Beukers-Stewart et al. 2003). In undisturbed populations, individuals may exceed $150 \mathrm{~mm}$ shell length and live for over $20 \mathrm{yr}$ (Tang 1941). There are 2 main spawning peaks in local populations each year, a partial spring spawning in April or May, and a more complete autumn spawning in August or September (Ansell et al. 1991). However, the spring spawning period is responsible for the vast majority of spat settlement, which occurs from June to August (Brand et al. 1980). Spat settlement and sub- sequent indices of recruitment (the density of $2 \mathrm{yr}$ olds) are highly variable between years (up to more than 35-fold; Beukers-Stewart et al. 2003). P. maximus is one of the most sedentary scallop species (Brand 1991); in a tagging study by (Howell \& Fraser 1984), $60 \%$ of individuals moved less than $30 \mathrm{~m}$ after $18 \mathrm{mo}$. The combination of fast growth, moderate longevity and sedentary nature suggested that $P$. maximus would be an ideal candidate for closed area management around the Isle of Man.

Dive surveys. To gain a long-term perspective on the effects of closed area protection on Pecten maximus populations, we combined our new study with the previous work done by Bradshaw et al. (2001). On this basis, dive surveys were conducted in the closed area most of the years between 1989 and 1998, and thereafter every year until 2003. Comparable surveys were done in the fished area off Bradda Head in 1989 once every 2 yr between 1996 and 2002 and again in 2003. All surveys were done during the closed season for $P$. maximus in the north Irish Sea (June to October inclusive). Between 1989 and 2000 (Bradshaw et al. 2001), surveys normally consisted of a varying number of haphazardly placed transects (50 $\mathrm{m}$ long by $4 \mathrm{~m}$ wide), swum by a pair of divers, with each diver surveying a parallel strip 2 m wide. From 2001 to 2003, a modified survey technique was used (our new study). During these surveys, divers counted and collected all P. maximus observed within transects and counted a range of other benthic species considered to be potential predators of $P$. maximus. These included edible crabs (Cancer pagurus) and starfish (Asterias rubens, Crossaster papposus, Luidia ciliaris, Marthasterias glacialis and Porania pulvillus). Transect width was reduced to $3 \mathrm{~m}$ (with each diver surveying a strip $1.5 \mathrm{~m}$ wide) but transect length varied from 30 to $200 \mathrm{~m}$ (the mean over the

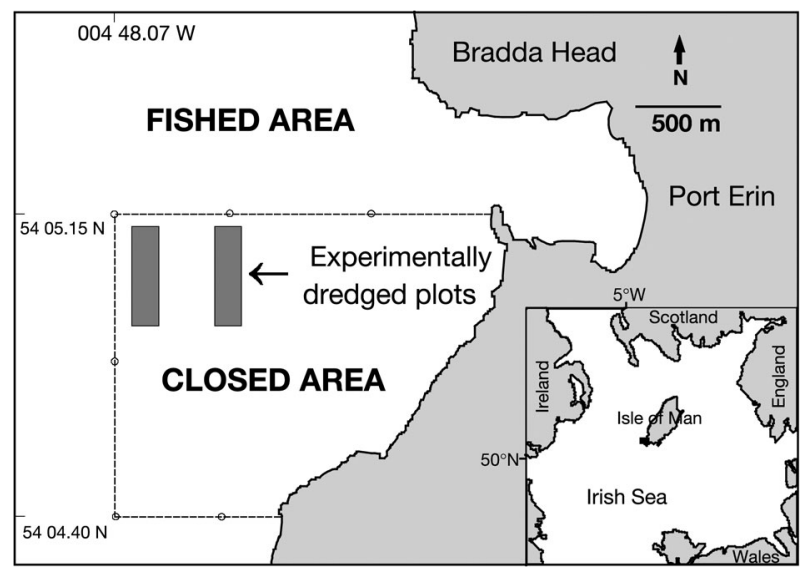

Fig. 1. Map of the closed and fished areas sampled during the study. Inset shows the location of the Isle of Man within the British Isles 
3 yr was $90.19 \pm 8.69 \mathrm{~m} \mathrm{SE}$ ). The longer, but variable nature of these transects resulted from divers swimming as far as air and decompression requirements allowed. Six surveys were done in the closed area in 2001 (total area $1188 \mathrm{~m}^{2}$ ), compared to 9 in 2002 and 8 in 2003 (total areas of 2562 and $1375 \mathrm{~m}^{2}$, respectively) and 8 in the fished area in both 2002 and 2003 (total areas of 3057 and $2632 \mathrm{~m}^{2}$, respectively). It was envisaged that this survey method would be more suitable for censusing populations of $P$. maximus, which are known to have a very patchy distribution on the seabed around the Isle of Man (Beukers-Stewart et al. 2001, Bradshaw et al. 2001). If successful, this method would therefore increase our ability to detect differences between the closed and fished areas on the Bradda Inshore fishing ground.

The length of diver survey transects was measured in 2 different ways between 2001 and 2003. In all years, the start of the surveys was marked with a buoyed shot line, the position of which was determined using a differential global positioning system (DGPS). Divers swam out from this position on a straight-line compass course in the direction of any existing current. At the end of each survey, the divers released a surface marker buoy (SMB) and its position was also determined using DGPS. The distance between these 2 readings therefore gave an estimate of transect length. The accuracy of DGPS measurement was assessed in 2002 and 2003 using a different method. During these surveys, divers also carried a $200 \mathrm{~m}$ reel of rope that was clipped to the shot line at the start of each survey and released as the divers swam along. Subsequent measurement of this rope gave an independent estimate of the distance travelled on each transect. There was a significant linear relationship between the distances measured by the 2 methods (DGPS $=1.03 \times$ rope $\left.+6.23 ; \mathrm{df}=1.26 ; \mathrm{R}^{2}=0.87, \mathrm{p}<0.01\right)$. A slope of 1 and an intercept of 0 fell within the $95 \%$ confidence intervals of the equation (slope 0.87 to 1.20 , intercept -13.40 to 25.86). In light of these results, we used DGPS measurements in 2001, and in 2002 and 2003 when ropebased measurements were not available. For all other calculations, we used rope-based measurements.

All scallops Pecten maximus collected by the divers between 2001 and 2003 were aged using validated annual growth rings (Allison et al. 1994), and measured to the nearest millimetre (shell length: SL). Each scallop was then dissected and the wet adductor muscle weight and wet gonad weight was measured separately to $0.01 \mathrm{~g}$.

Dredge surveys. Dredge surveys of the abundance, size and age of Pecten maximus on the Bradda Inshore fishing ground (the fished area) were done every June and October between 1991 and 2003, using the RV 'Roagan', a $24 \mathrm{~m}$ converted beam trawler (Beukers-
Stewart et al. 2003). This dataset was used to provide additional density data in 2001 and size-at-age data from 2000 to 2003 (see below). On one side of the research vessel, a gang of 4 standard commercial scallop dredges was fished, while on the other side, 4 queen scallop Aequipecten opercularis dredges were used. All dredges were $0.76 \mathrm{~m}$ in width. The queen dredges differ from the scallop dredges in having 10 teeth of $60 \mathrm{~mm}$ length (compared to 9 teeth of $110 \mathrm{~mm}$ ) and belly rings of $55 \mathrm{~mm}$ internal diameter (compared to $80 \mathrm{~mm}$ ). These queen dredges were used to increase the sample size of small scallops below the minimum legal landing size (110 mm SL) (BeukersStewart et al. 2001, 2003).

The efficiency of the queen dredges for catching scallops as a function of size was determined by comparing the results of dredge surveys in June 2000 (Beukers-Stewart et al. 2003) with dive surveys in July 2000 (Beukers-Stewart et al. 2001). The queen dredges were found to be $21.6 \%$ efficient for scallops in the 70 to $89 \mathrm{~mm}$ SL size range and $43.0 \%$ efficient for scallops in the 90 to $109 \mathrm{~mm}$ SL size range. These values were used to calculate the absolute density of $2 \mathrm{yr}$ old scallops in the fished area in October 2001, for use in the estimation of mortality (see below). The scallop dredges are known to be $33.33 \%$ efficient for older $(\geq 3 \mathrm{yr})$ and larger $(\geq 110 \mathrm{~mm})$ scallops (BeukersStewart et al. 2001). This value was used to calculate the absolute density of these scallops in the fished area in October 2001.

Experimental dredging of the closed area. Two plots within the closed area (each approximately $500 \times$ $100 \mathrm{~m}$ ) were experimentally dredged once every 2 mo between January 1995 and June 2000 (Bradshaw et al. 2001). Two gangs of 4 scallop dredges were towed along the length of each plot 10 times on each date. Consecutive tows were done in parallel so that (on average) the whole plot was covered at least once during each dredging exercise. Any scallops captured during this process were transferred to another area several kilometres away from the study sites. This dredging exercise was designed to simulate commercial exploitation, although the Bradda Inshore ground commonly experiences higher levels of fishing effort (Veale et al. 2000). It should be noted, however, that experimental dredging continued throughout the closed season for Pecten maximus (June to October). The effect of this disturbance on the population structure of $P$. maximus was investigated by comparing the size and age structure of scallops ( $\geq 110 \mathrm{~mm} \mathrm{SL}$ ) taken by scallop dredges in 3 different areas (experimental area, fished area and closed area) in April and June 2000. Experimental area samples were collected during the final experimental dredging exercise, while fished-area data came from the dredge survey dataset 
(see above). The closed area samples came from the catch of a commercial boat fishing illegally in the closed area. On a single morning in April 2000, this boat spent approximately $3 \mathrm{~h}$ towing up and down the previously undisturbed section of the closed area. Effort was concentrated in the offshore half of the closed area although the boat occasionally ventured closer inshore. The dredges were hauled and the catch sorted twice during this period. This entire catch was later obtained for biometric analysis.

Data analysis. Population dynamics and structure of Pecten maximus: Densities of $P$. maximus in the closed and fished areas were compared each year from 2001 to 2003. In 2001, analysis was restricted to legal-sized scallops $(\geq 110 \mathrm{~mm})$ taken by the dive survey in the closed area (August) and by the dredge survey in the fished area (October). In 2002 and 2003, analysis was based solely on the dive surveys in the 2 areas (August to October), with 2-way ANOVA comparing the density of all scallops and scallops $\geq 110 \mathrm{~mm}$ only. The 2 fixed factors were year and area of survey. Data for scallops $\geq 110 \mathrm{~mm}$ were $\log (x+1)$ transformed to meet assumptions of normality and heterogeneity (Cochran's C-test, p > 0.05; Underwood 1981). Density of all scallops within the inshore ( $<28 \mathrm{~m}$ water depth) and offshore portions of the closed area was also compared in 2002 and 2003 (analysis as above). This investigated the hypothesis that scallop densities would be higher inshore than offshore, due to the possibility that illegal fishing would occasionally occur close to the boundary. For the fished area, we also examined the relationship between distance from the closed area boundary and the density of all scallops (analysis as above). This investigated the hypothesis that scallop densities in the fished area would be higher close to the fished area boundary (within $1 \mathrm{~km}$ north) than further away (1 to $2 \mathrm{~km}$ north), due to spillover (or movement) of scallops from the closed to fished areas.

Size and age structures of scallops collected from the closed and fished areas were also compared (Kolmogorov-Smirnov analysis) using the same samples as above. The relationships between scallop length and both exploitable biomass (adductor muscle and gonad weight combined) and reproductive biomass (gonad weight only) were then determined from biometric measurements. A number of scallops spawned between collection and subsequent measurement, presumably due to disturbance (e.g. aerial exposure). However, Pecten maximus in the Irish Sea normally have full gonads during August and September (Ansell et al. 1991), the months during which the majority of surveys were conducted. Therefore, scallops that had clearly spawned $(37.5 \%$ of individuals over the $3 \mathrm{yr}$ ) were removed from the analysis in order to standardise biometric relationships. These relationships were then used to calculate estimates of exploitable biomass (adductor and gonad weights combined) and reproductive potential (gonad weights only) from the length of scallops ( $\geq 110 \mathrm{~mm}$ only) collected in the 2 areas each year.

Estimates of total mortality for the scallop populations in the closed and fished areas were calculated using catch curve analysis (Beverton \& Holt 1957). Using the above data sets, the mean density-at-age in the 2 areas was calculated using the years from 2001 to 2003 as replicates. One year old scallops were excluded from this analysis, as they were not adequately sampled (see discussion). The oldest year-class in each sample (14 and $7 \mathrm{yr}$, respectively) was also excluded from catch curve analysis as they were identified as outliers (see Cortes \& Parsons 1996). Regressions were then fitted to natural log-transformed densities to generate mortality estimates. The change in density of 2 yr old scallops over two, 1 yr periods (2001 to 2002 and 2002 to 2003) was also calculated for both the closed and fished areas. These scallops would have remained below the legal size throughout each ensuing fishing season, therefore, any difference between losses in the 2 areas could potentially be due to indirect fishing mortality. For the period between 2001 and 2002, density estimates of this cohort of scallops in the closed area were restricted to those survey dives in 2002 that were most similar in location to the ones done in 2001 (as the survey was more widespread in 2002). Density estimates for the fished area in 2001 were obtained from the queen dredge survey in October (after efficiency adjustments for the relevant size-classes) and the dive survey in September 2002. For the period between 2002 and 2003, all dive surveys were used to calculate density estimates. When methodology and sample size allowed (see results), these density estimates were compared by 1-way ANOVA. The density of potential scallop predators (other than Asterias rubens) in the 2 areas in 2002 and 2003 was also compared by 2-way ANOVA to assess any influence this may have had on results. The 2 fixed factors were year and area of survey. The density of $A$. rubens in the 2 areas was compared only in 2003 using 1 -way ANOVA (see results for explanation). These data were transformed $(\log x+1)$ to meet assumptions of normality and heterogeneity (as above).

Growth rates of Pecten maximus: Mean size-at-age of scallops in the closed and fished areas was calculated from the samples collected in 2002 and 2003. The data from 2001 were not included because samples were taken at different times of the year during the peak period of scallop growth (closed area: August, fished area: October). The closed area data were based entirely on samples collected by divers, while the fished area data included scallops from both divers and the October dredge surveys (in order to boost sample 
sizes). Analysis was restricted to scallops up to $10 \mathrm{yr}$ old (as only small numbers of older individuals were collected). Von Bertalanffy growth curves were fitted to each sample and the closed and fished areas were compared in each year using the likelihood ratio test (Kimura 1980). This tested the null hypothesis that the separate growth curves were not significantly different from a co-incident curve based on combining the samples. The mean size of scallops at ages 1 to 3 was also compared between areas in each year using 1-way ANOVA.

Effect of dredging on Pecten maximus population structure: The size and age structures of scallops from the 3 areas (closed, experimentally dredged and open to fishing) were compared by Kolmogorov-Smirnov analysis. Catch curve analysis was also performed on the age structure data to provide estimates of total mortality in the 3 areas. Three year old scallops were excluded from this analysis, as they were not adequately sampled.

\section{RESULTS}

\section{Population dynamics and structure of Pecten maximus}

When the closed area was set up in 1989, scallop density was very low (approx. 0.5/100 $\mathrm{m}^{2}$ ) in both the closed and fished areas, which at the time were parts of the same fishing ground (Fig. 2). Between 1989 and 1998 there was a slow but gradual increase in scallop density in the closed area (up to $3.5 / 100 \mathrm{~m}^{2}$ ), but over

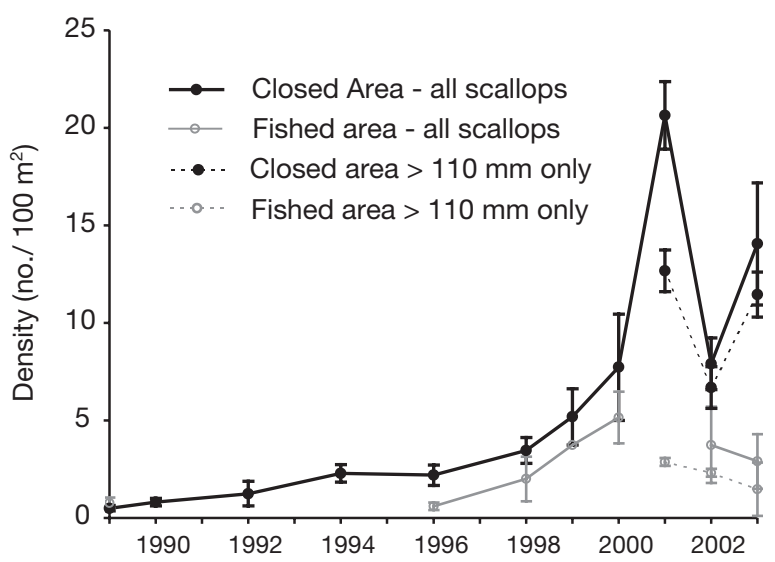

Fig. 2. Pecten maximus. Density (mean no./100 $\mathrm{m}^{2} \pm \mathrm{SE}$ ) estimated by dive surveys in the closed and fished areas between 1989 and 2003. The exception is the estimate for scallops $\geq 110 \mathrm{~mm}$ in the fished area in 2001 that was taken from the dredge survey dataset after correction for dredge efficiency (see text for details) the next 3 yr density increased at a rapid rate, reaching a peak of over $20 / 100 \mathrm{~m}^{2}$ in 2001 , before dropping in 2002 and then rising again in 2003. Scallop densities in the area open to fishing have consistently remained below those in the closed area. These densities also increased in the late 1990s, but not to the extent seen in the closed area, and they dropped, rather than rose, between 2002 and 2003. In 2001, the density of legalsized scallops ( $\geq 110 \mathrm{~mm} \mathrm{SL}$ ) was 4.5 times higher in the closed area than that estimated by dredge surveys in the fished area $\left(12.93 / 100 \mathrm{~m}^{2}\right.$ compared to 2.87 / $100 \mathrm{~m}^{2}$ ) (Fig. 2). However, due to differences in sampling methodology this difference could not be tested statistically.

In 2002 and 2003, when divers surveyed both areas, the densities of all scallops and legal-sized scallops were highly significantly different in the 2 areas (Table 1, Fig. 2). In 2002, the density of all scallops was 2.11 times higher in the closed area than in the fished area $\left(7.91 / 100 \mathrm{~m}^{2}\right.$ compared to $\left.3.75 / 100 \mathrm{~m}^{2}\right)$, and in 2003 this increased to 4.85 times higher $\left(14.05 / 100 \mathrm{~m}^{2}\right.$ in the closed area compared to $2.90 / 100 \mathrm{~m}^{2}$ in the fished area). Differences for legal-sized scallops were even more dramatic (Table 1, Fig. 2). In 2002 the density of legal-sized scallops in the closed area was $6.55 / 100 \mathrm{~m}^{2}$ compared to 2.27 in the fished area (2.89 times higher), while in 2003 the density of legalsized scallops was $11.45 / 100 \mathrm{~m}^{2}$ in the closed area compared to $1.47 / 100 \mathrm{~m}^{2}$ in the fished area $(7.76$ times higher). Despite a trend for scallop densities to be higher in the inshore section of the closed area $(<28 \mathrm{~m}$ water depth) than further offshore $\left(9.99 / 100 \mathrm{~m}^{2}\right.$ compared to $6.24 / 100 \mathrm{~m}^{2}$ in 2002 and $15.15 / 100 \mathrm{~m}^{2}$ compared to $12.94 / 100 \mathrm{~m}^{2}$ in 2003), these differences were not significant (Table 2a). There was also a trend for the density of scallops within $1 \mathrm{~km}$ north of the closed area boundary to be lower than that further away (1 to $2 \mathrm{~km}$ north), (1.95/100 $\mathrm{m}^{2}$ compared to 5.54/100 $\mathrm{m}^{2}$ in 2002 and $0.94 / 100 \mathrm{~m}^{2}$ compared to $4.87 / 100 \mathrm{~m}^{2}$ in

Table 1. Pecten maximus. Two-way ANOVA comparing density in the closed and fished areas in 2002 and 2003. (a) All scallops; (b) scallops $\geq 110 \mathrm{~mm}$ SL only ( $\log x+1$ transformed). ${ }^{*}$ Significant difference

\begin{tabular}{|lrrrrr|}
\hline Source & SS & df & MS & $F$ & $p$ \\
\hline (a) & & & & & \\
Year & 57.55 & 1 & 57.55 & 1.66 & 0.21 \\
Area & 482.03 & 1 & 482.03 & 13.93 & $<0.01^{*}$ \\
Year $\times$ Area & 100.28 & 1 & 100.28 & 2.90 & 0.10 \\
Residual & 1003.34 & 29 & 34.60 & & \\
(b) & & & & & \\
Year & $3.12 \mathrm{E}-02$ & 1 & $3.12 \mathrm{E}-02$ & 0.33 & 0.57 \\
Area & 2.83 & 1 & 2.83 & 30.14 & $<0.01^{*}$ \\
Year $\times$ Area & 0.12 & 1 & 0.12 & 1.31 & 0.26 \\
Residual & 2.72 & 29 & $9.39 \mathrm{E}-02$ & & \\
\hline
\end{tabular}


Table 2. Pecten maximus. Two-way ANOVA comparing density (a) in the inshore and offshore sections of the closed area in 2002 and 2003; and (b) in the areas from 0-1 and $1-2 \mathrm{~km}$ outside the closed area boundary in 2002 and 2003 $\log x+1$ transformed)

\begin{tabular}{|lrrrrr|}
\hline Source & SS & df & MS & $F$ & $p$ \\
\hline (a) & & & & & \\
Year & 147.99 & 1 & 147.99 & 3.01 & 0.11 \\
Section & 37.56 & 1 & 37.56 & 0.77 & 0.40 \\
Year $\times$ Section & 2.50 & 1 & 2.50 & 0.05 & 0.83 \\
Residual & 638.28 & 13 & 49.10 & & \\
(b) & & & & & \\
Year & 0.01 & 1 & 0.01 & 0.07 & 0.79 \\
Area & 0.34 & 1 & 0.34 & 2.42 & 0.15 \\
Year $\times$ Area & 0.03 & 1 & 0.03 & 0.18 & 0.68 \\
Residual & 1.68 & 12 & 0.14 & & \\
\hline
\end{tabular}

2003), but the data were highly variable and the differences were not significant (Table $2 b$ ).

The age and size structures of scallops collected from the closed area during the dive surveys from 2001 to 2003 were compared to those collected in the fished area during dredge surveys in 2001 and by divers in

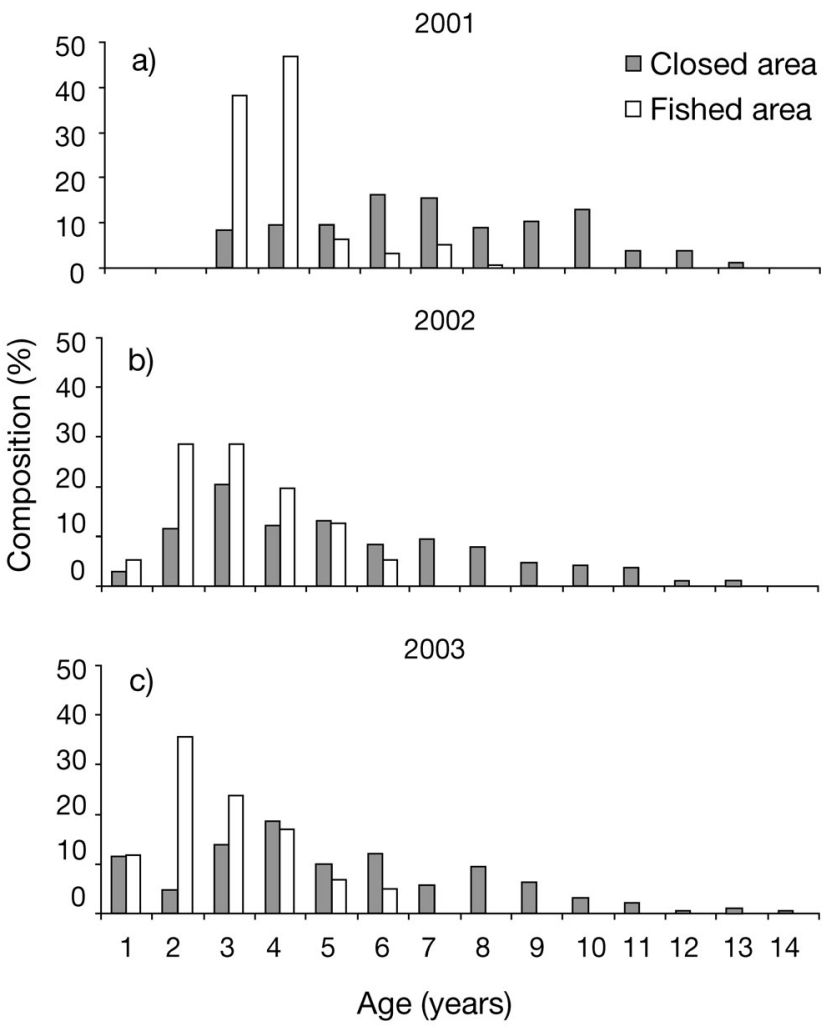

Fig. 3. Pecten maximus. Age composition within the closed and fished areas. All scallops collected by divers except for the fished area in 2001 (collected by dredges). (a) 2001 (scallops $\geq 110 \mathrm{~mm}$ only): closed area $\mathrm{n}=156$, fished area $\mathrm{n}=323$; (b) 2002 (all scallops): closed area $\mathrm{n}=215$, fished area $\mathrm{n}=56$; (c) 2003 (all scallops): closed area $n=189$, fished area $n=59$

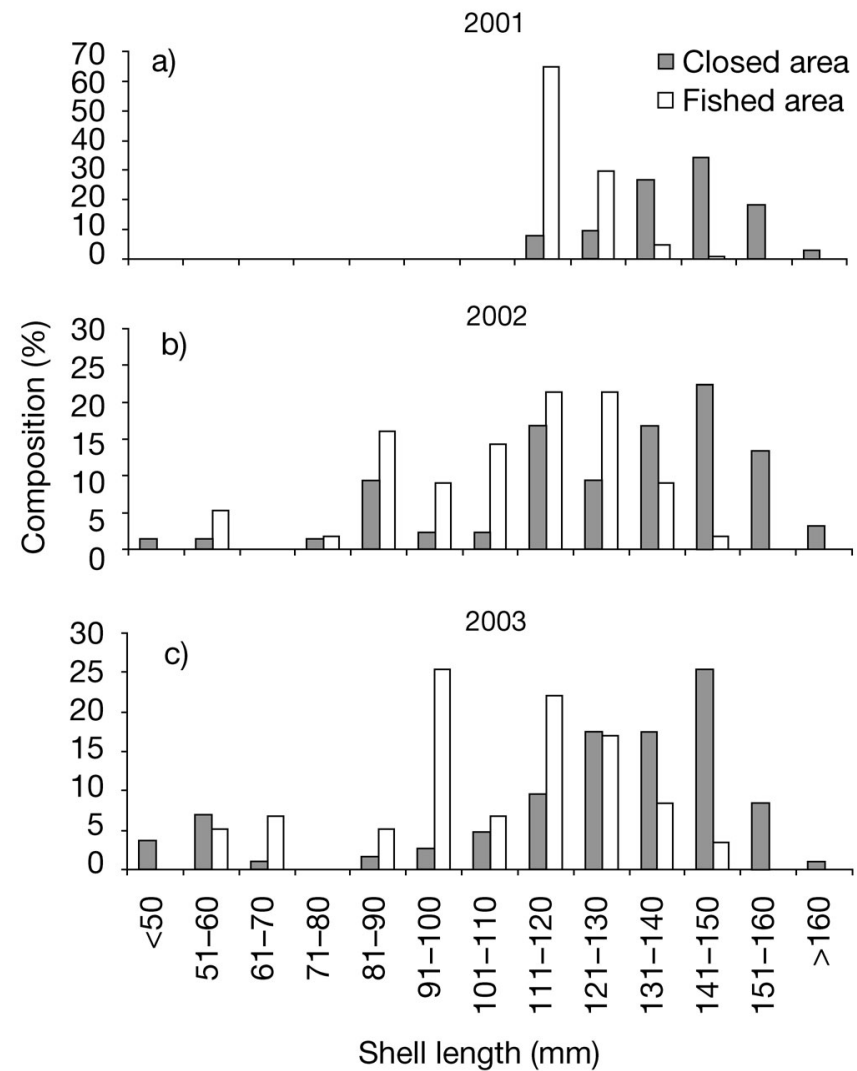

Fig. 4. Pecten maximus. Length composition within the closed and fished areas. All scallops collected by divers except for the fished area in 2001 (collected by dredges). (a) 2001 (scallops $\geq 110 \mathrm{~mm}$ only): closed area $\mathrm{n}=156$, fished area $\mathrm{n}=323$; (b) 2002 (all scallops): closed area $\mathrm{n}=215$, fished area $\mathrm{n}=56$; (c) 2003 (all scallops): closed area $\mathrm{n}=189$, fished area $\mathrm{n}=59$

2002 and 2003 (Figs. 3 \& 4). In all years, a shift towards older and larger scallops in the closed area was apparent. By $2003,41.3 \%$ of scallops in the closed area were older than 5 yr, compared to only $5.1 \%$ of scallops from the fished area (Fig. 3). Likewise, in the same year, $52.4 \%$ of the scallops in the closed area were larger than $130 \mathrm{~mm}$ compared to only $11.9 \%$ of those from the fished area (Fig. 4). All comparisons revealed highly significant differences (Table 3).

Patterns of density, size and age structure of the scallops in the 2 areas had dramatic implications for differences in scallop biomass and reproductive potential (Table 4). In 2001, the exploitable biomass (adductor muscle and gonad weight) of scallops in the closed area was over 8 times higher than in the fished area, and the reproductive potential (gonad weight) was over 10 times higher. Differences between the 2 areas were reduced in 2002, but were still substantial. Exploitable biomass was nearly 5 times higher in the closed area and gonad biomass was nearly 6 times higher. In 2003, differences reached their most extreme level, with exploitable biomass nearly 11 times 
Table 3. Pecten maximus. Kolmogorov-Smirnov (K-S) 2 sample tests comparing population structure in the closed and fished area from 2001 to 2003. All comparisons were significant. (a) Age structure; (b) size structure

\begin{tabular}{|lcccc|}
\hline Year & $\begin{array}{c}\text { Closed area } \\
(\mathrm{n})\end{array}$ & $\begin{array}{c}\text { Fished area } \\
(\mathrm{n})\end{array}$ & $\begin{array}{c}\mathrm{K}-\mathrm{S} \\
Z\end{array}$ & $\mathrm{p}$ \\
\hline (a) & & & & \\
2001 & 156 & 323 & 6.86 & $<0.01$ \\
2002 & 215 & 56 & 2.34 & $<0.01$ \\
2003 & 189 & 59 & 2.75 & $<0.01$ \\
(b) & & & & \\
2001 & 156 & 323 & 7.84 & $<0.01$ \\
2002 & 215 & 56 & 3.00 & $<0.01$ \\
2003 & 189 & 59 & 2.86 & $<0.01$ \\
\hline
\end{tabular}

higher in the closed area than in the fished area and reproductive biomass 12.5 times higher.

The mean density-at-age data for the period 2001 to 2003 (Fig. 5a) also revealed distinct differences between the dynamics of scallop populations in the 2 areas. Catch curve analysis of these data (natural log transformed) produced strong linear regressions that estimated total mortality of scallops in the fished area $(Z=0.76)$ to be almost 3.5 times higher than in the closed area $(Z=0.22)$ (Fig. $5 b)$. There were also considerable differences between the 2 areas when loss rates of scallops between 2 and 3 yr old were examined (Table 5). In both the closed and the fished areas, the density of 2 yr olds (the 1999 year-class) was particularly high, but very similar; in 2001 with mean densi- ties of approximately 5.3/100 $\mathrm{m}^{2}$. Between the surveys in 2001 and 2002, the density of this year-class declined by $56.2 \%$ in the closed area compared to $79.9 \%$ in the fished area (a difference of $23.7 \%$ ). As a result, 3 yr old scallops were more than twice as abundant in the closed area than in the fished area in 2002 (Table 5). Unfortunately, differences in sampling methods and replication precluded statistical analysis of these results. In 2002 the density of the 2 yr old cohort (the 2000 year-class) was much lower (approximately $1 / 100 \mathrm{~m}^{2}$ ) but was again very similar in the 2 areas (1-way ANOVA, $F_{1,16}=0.70, \mathrm{p}=0.79$, not significant). By 2003 the density of this year-class had declined by $35.8 \%$ in the fished area, but had increased by $110.4 \%$ in the closed area (Table 5). These densities were significantly different (1-way ANOVA, $F_{1,15}=$ 5.25, $\mathrm{p}=0.04)$.

The mean density of potential scallop predators (other than Asterias rubens) was not significantly different between the 2 areas in 2002 or 2003 (Table 6). Overall, predator numbers were significantly higher in 2003 than 2002 (Table 6). In 2002, $95 \%$ of the A. rubens counted were less than $5 \mathrm{~cm}$ in diameter (i.e. they would have recruited during the summer of 2002) and therefore were not considered as predators of 2 to $3 \mathrm{yr}$ old scallops (Whittington 1993). In 2003, when most of the $A$. rubens had reached a diameter of 10 to $15 \mathrm{~cm}$ (i.e. a size at which they could consume scallops; Whittington 1993), density estimates were significantly higher in the fished area $\left(8.97 / 100 \mathrm{~m}^{2}\right.$ compared to $0.67 / 100 \mathrm{~m}^{2}$ ) (1-way ANOVA, $\left.F_{1,14}=7.916, \mathrm{p}=0.014\right)$.

Table 4. Pecten maximus. Comparison of density and exploitable and reproductive biomass estimates in the closed and fished area from 2001 to 2003 (scallops $\geq 110 \mathrm{~mm}$ SL only)

\begin{tabular}{|c|c|c|c|c|c|}
\hline \multirow[t]{2}{*}{ Year/area } & \multirow{2}{*}{$\begin{array}{c}\text { Mean scallop density } \\
\text { Per } 100 \mathrm{~m}^{2}\end{array}$} & \multicolumn{2}{|c|}{$\begin{array}{l}\text { Mean exploitable biomass ( } \mathrm{g} \text { ) } \\
\text { (adductor muscle \& gonad weight) }\end{array}$} & \multicolumn{2}{|c|}{$\begin{array}{l}\text { Mean reproductive biomass ( } g \text { ) } \\
\text { (gonad weight only) }\end{array}$} \\
\hline & & Per scallop & Per $100 \mathrm{~m}^{2}$ & Per scallop & Per $100 \mathrm{~m}^{2}$ \\
\hline \multicolumn{6}{|l|}{ (a) Estimates } \\
\hline \multicolumn{6}{|l|}{2001} \\
\hline Closed area & 12.93 & 60.34 & 780.21 & 8.42 & 108.81 \\
\hline Fished area & 2.87 & 33.72 & 96.79 & 3.61 & 10.35 \\
\hline Ratio & $\times 4.51$ & $\times 1.79$ & $\times 8.06$ & $\times 2.33$ & $\times 10.51$ \\
\hline \multicolumn{6}{|l|}{2002} \\
\hline Closed area & 6.55 & 72.89 & 477.29 & 21.43 & 140.34 \\
\hline Fished area & 2.27 & 44.77 & 101.82 & 10.41 & 23.67 \\
\hline Ratio & $\times 2.89$ & $\times 1.63$ & $\times 4.69$ & $\times 2.06$ & $\times 5.93$ \\
\hline \multicolumn{6}{|l|}{2003} \\
\hline Closed area & 11.45 & 59.45 & 608.6 & 18.30 & 209.55 \\
\hline Fished area & 1.47 & 42.03 & 61.97 & 11.35 & 16.73 \\
\hline Ratio & $\times 7.76$ & $\times 1.41$ & $\times 10.98$ & $\times 1.61$ & $\times 12.52$ \\
\hline \multicolumn{6}{|c|}{ (b) Biometric relationships used in the above calculations } \\
\hline \multicolumn{6}{|c|}{ Exploitable biomass: } \\
\hline \multicolumn{3}{|c|}{$2001=(\text { Shell length })^{3.337} \times 0.000004$} & \multicolumn{2}{|c|}{$\begin{array}{l}\text { Reproductive biomass: } \\
2001=(\text { Shell length })^{4.794} \times 0.00000000004\end{array}$} & $\mathrm{R}^{2}=0.90$ \\
\hline \multicolumn{2}{|c|}{$2002=(\text { Shell length })^{3.512} \times 0.000002$} & $\mathrm{R}^{2}=0.97$ & & $\mathrm{R}^{2}=0.89$ \\
\hline \multicolumn{2}{|c|}{$2003=(\text { Shell length })^{3.777} \times 0.0000005$} & $\mathrm{R}^{2}=0.99$ & \multicolumn{2}{|c|}{$\begin{array}{l}2002=(\text { Shell length })^{5.122} \times 0.0000000002 \\
2003=(\text { Shell length })^{5.121} \times 0.0000000002\end{array}$} & $\mathrm{R}^{2}=0.97$ \\
\hline
\end{tabular}




\section{Growth rates of Pecten maximus}

The likelihood ratio test results indicated that the von Bertalanffy growth curves fitted to the mean sizeat-age data from the closed and fished areas were significantly different in both 2002 and 2003 (Table 7, Fig. 6). The general pattern was for mean size-at-age to be similar in the 2 areas at age 1 , but to diverge at 2 or $3 \mathrm{yr}$ old. This resulted in mean size-at-age of scallops from the closed area being greater than in the fished area for scallops 3 yr and older in 2002, and scallops 2 yr and older in 2003 (Table 7, Fig. 6). However, in 2003, 1 yr old scallops were slightly, but significantly larger in the fished area than the closed area (Table 7), indicating that the pattern reversed between 1 and $2 \mathrm{yr}$ old. It should be noted that mean size at age is the end product of patterns of both growth and survival. For example, for scallops of $4 \mathrm{yr}$ and older, the observed differences between the 2 areas may have resulted from the selective removal of faster growing individu-
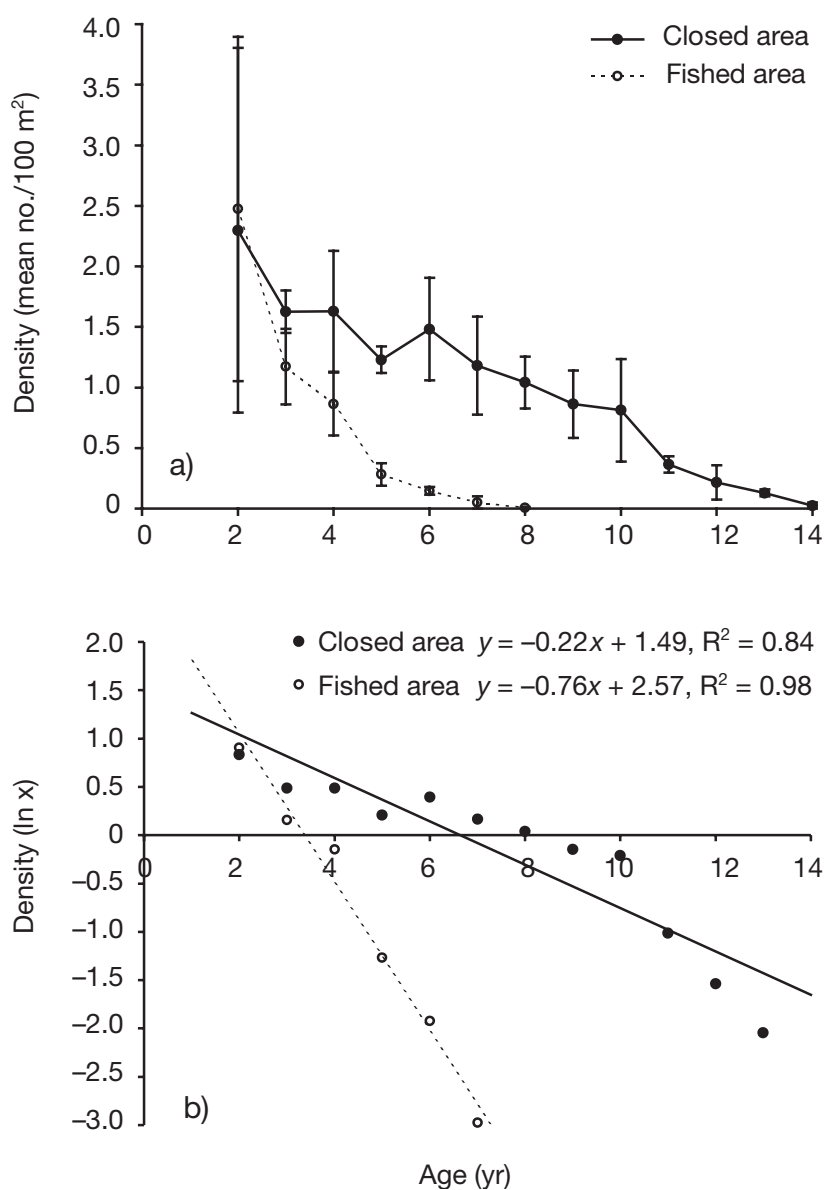

Fig. 5. Pecten maximus. (a) Density (mean no./100 $\mathrm{m}^{2} \pm \mathrm{SE}$ ) per age-class in the closed and fished areas (2001 to 2003).

(b) Catch curve analysis (total mortality estimates) for the closed and fished area populations (2001 to 2003)
Table 5. Pecten maximus. Density estimates and loss rates of scallops between 2 and $3 \mathrm{yr}$ old in the closed and fished areas. (a) The 1999 year-class between 2001 and 2002; (b) the 2000 year-class between 2002 and 2003

\begin{tabular}{|lccccr|}
\hline Area & $\begin{array}{c}\text { Density } \\
\left(\text { no./100 } \mathrm{m}^{2}\right)\end{array}$ & SE & $\begin{array}{c}\text { Density } \\
\left(\text { no./100 m }{ }^{2}\right)\end{array}$ & SE & $\begin{array}{c}\text { Loss } \\
(\%)\end{array}$ \\
\hline (a) & $\underline{2001}$ & & $\underline{2002}$ & & \\
Closed & 5.30 & 0.45 & 2.33 & 0.21 & 56.15 \\
Fished & 5.32 & 0.23 & 1.07 & 0.56 & 79.88 \\
(b) & $\underline{2002}$ & & $\underline{2003}$ & & \\
Closed & 0.92 & 0.15 & 1.93 & 0.43 & -110.34 \\
Fished & 1.07 & 0.56 & 0.69 & 0.33 & 35.77 \\
\hline
\end{tabular}

als by the fishery. Therefore, it is not possible to attribute this difference to the growth rate. However, until October of each year (the end of each survey period), scallops up to $3 \mathrm{yr}$ old would not have been subject to direct removal by fishing (as they were previously below the minimum legal landing size).

\section{Effect of dredging on population structure of Pecten maximus}

Age and size (of scallops $\geq 110 \mathrm{~mm}$ ) in the experimentally dredged plots within the closed area were similar to that in the fished area (Fig. 7). For example, in the fished and experimental plots, only 19.8 and $7.7 \%$, respectively, of scallops were greater than $6 \mathrm{yr}$ old, with less than $5 \%$ being greater than 8 yr old. These age compositions were not significantly different (Table 8). Likewise, in the fished and experimental plots, only 34.0 and $22.8 \%$, respectively, of scallops were larger than $130 \mathrm{~mm} \mathrm{SL}$, with none greater than $150 \mathrm{~mm}$ SL. However, these size compositions were significantly different, probably due to a higher proportion of scallops in 110 to $119 \mathrm{~mm}$ size range in the disturbed area than the fished area $(48.8 \%$ compared to $25.8 \%$ ). In comparison, scallops from the undisturbed region of the closed area were significantly older and larger than at both other sites (Table 8,

Table 6. Two-way ANOVA comparing the density of scallop predators (crabs and starfish other than Asterias rubens; see text for details) in the closed and fished areas in 2002 and 2003. * Significant difference

\begin{tabular}{|lrrrcc|}
\hline Source & SS & df & MS & $F$ & p \\
\hline Year & 37.40 & 1 & 37.40 & 5.19 & $0.03^{*}$ \\
Area & 13.03 & 1 & 13.03 & 1.81 & 0.19 \\
Year $\times$ area & 1.50 & 1 & 1.50 & 0.21 & 0.65 \\
Residual & 209.07 & 29 & 7.21 & & \\
\hline
\end{tabular}


Table 7. Pecten maximus. (a) Von Bertalanffy growth curve parameters and likelihood ratio test results for scallops in the closed and fished areas and combined, in 2002 and 2003. (b) Comparison of mean size (mm SL) at age for scallops aged 1 to 3 yr in the closed and fished areas in 2002 and 2003. *Significant difference

\begin{tabular}{|c|c|c|c|c|c|c|}
\hline \multirow{2}{*}{$\begin{array}{l}\text { (a) } \\
\text { Parameters }\end{array}$} & \multicolumn{3}{|c|}{2002} & \multicolumn{3}{|c|}{-2003} \\
\hline & Closed area & Fished area & Co-incident & Closed area & Fished area & Co-incident \\
\hline $\mathrm{L}_{\infty}$ & 152.90 & 138.25 & 152.39 & 147.94 & 138.99 & 147.47 \\
\hline $\mathrm{k}$ & 0.48 & 0.52 & 0.42 & 0.52 & 0.46 & 0.44 \\
\hline$t_{0}$ & 0.18 & 0.08 & -0.01 & 0.12 & -0.14 & -0.11 \\
\hline \multicolumn{7}{|l|}{ Results } \\
\hline $\mathrm{RSS}_{\omega}$ & & & 332.16 & & & 351.85 \\
\hline$\chi^{2}$ & & & 36.21 & & & 40.92 \\
\hline df & & & 3 & & & 3 \\
\hline $\mathrm{p}$ & & & $<0.01^{*}$ & & & $<0.01^{*}$ \\
\hline
\end{tabular}

\begin{tabular}{|c|c|c|c|c|c|c|c|c|}
\hline \multirow{2}{*}{$\begin{array}{l}\text { (b) } \\
\text { Age }\end{array}$} & \multicolumn{4}{|c|}{$2002-$} & \multicolumn{4}{|c|}{2003} \\
\hline & Closed area & Fished area & F-ratio & $\mathrm{p}$ & Closed area & Fished area & F-ratio & $\mathrm{p}$ \\
\hline 1 & 50.67 & 53.50 & $1.35_{1,11}$ & 0.27 & 53.27 & 57.77 & $6.03_{1,34}$ & $0.02 *$ \\
\hline 2 & 85.49 & 85.48 & $0.01_{1,293}$ & 0.99 & 94.00 & 85.75 & $20.06_{1,353}$ & $<0.01^{*}$ \\
\hline 3 & 115.5 & 109.84 & $35.24_{1,371}$ & $<0.01^{*}$ & 115.23 & 107.05 & $47.21_{1,330}$ & $<0.01^{*}$ \\
\hline
\end{tabular}
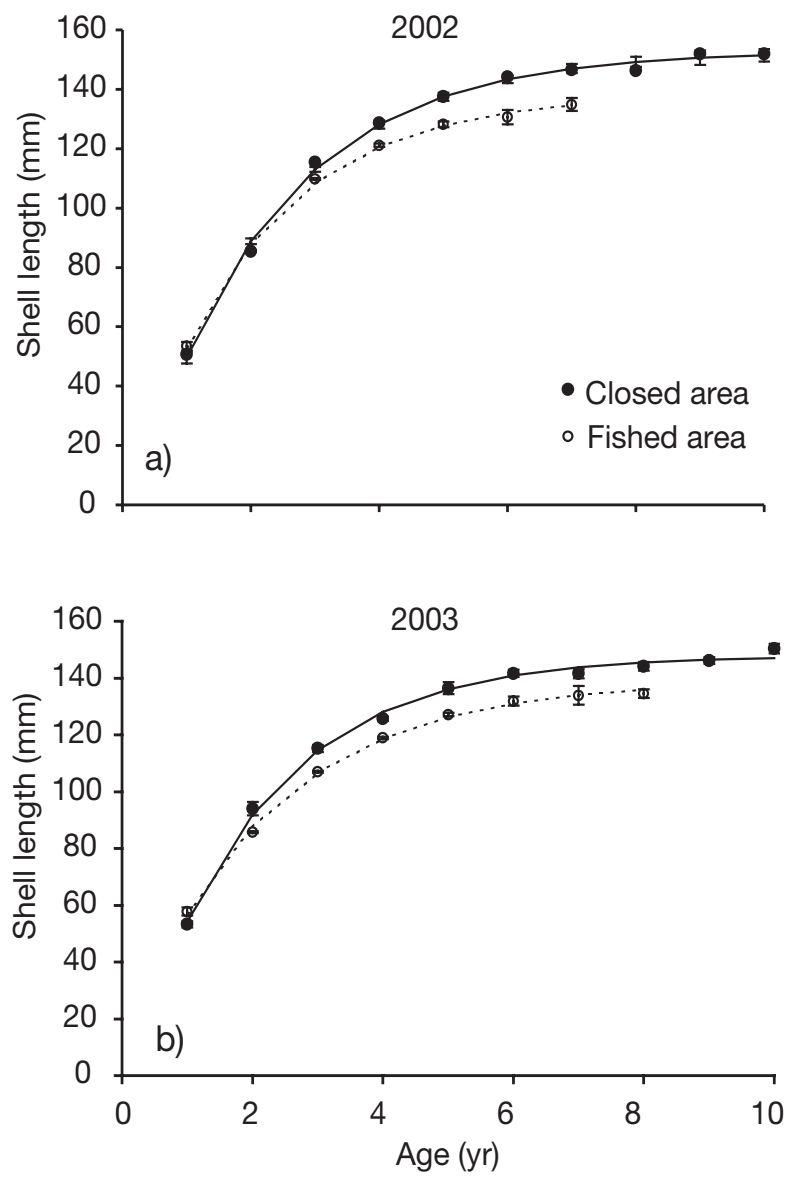

Fig. 6. Pecten maximus. Size-at-age (mean $\pm \mathrm{SE}$ ) and von Bertalanffy growth curves in the closed and fished areas in 2002 and 2003. (a) 2002: closed area $\mathrm{n}=203$, fished area $\mathrm{n}=$ 768; (b) 2003: closed area $\mathrm{n}=182$, fished area $\mathrm{n}=965$
Fig. 7). In the closed area, $45.1 \%$ of scallops were older than $6 \mathrm{yr}$, and $71.4 \%$ were greater than $130 \mathrm{~mm} \mathrm{SL}$, with $11.3 \%$ greater than $150 \mathrm{~mm}$ SL.

Catch curve analysis also produced different estimates of total mortality for scallops in the 3 areas (Fig. 7). Mortality estimates were highest in the experimental area $(Z=0.74)$, intermediate in the fished area $(Z=0.47)$ and lowest in the undisturbed region of the closed area $(Z=0.30)$. However, it should be noted that catch curve analysis of the closed area data produced a relatively weak regression $\left(R^{2}=0.58\right)$.

\section{DISCUSSION}

In common with a growing number of studies (for recent reviews see Mosquera et al. 2000, Halpern \& Warner 2002, Gell \& Roberts 2003, Halpern 2003), our work demonstrated that closed area protection results in increases in the density and mean age and size of exploited species. Experimental dredging within the closed area confirmed that these observations were largely in response to decreased fishing activity. This is significant for fisheries management because the build up of high densities of large Pecten maximus individuals enhanced local reproductive potential and therefore the likelihood of larval export to the surrounding fishing grounds. Our work also suggested that protecting juvenile scallops from fishing disturbance increased survival and growth rates. Although juvenile scallops are not subject to direct removal by fishing, protection during this critical phase appeared to assist the recovery of the closed area population. Our study 

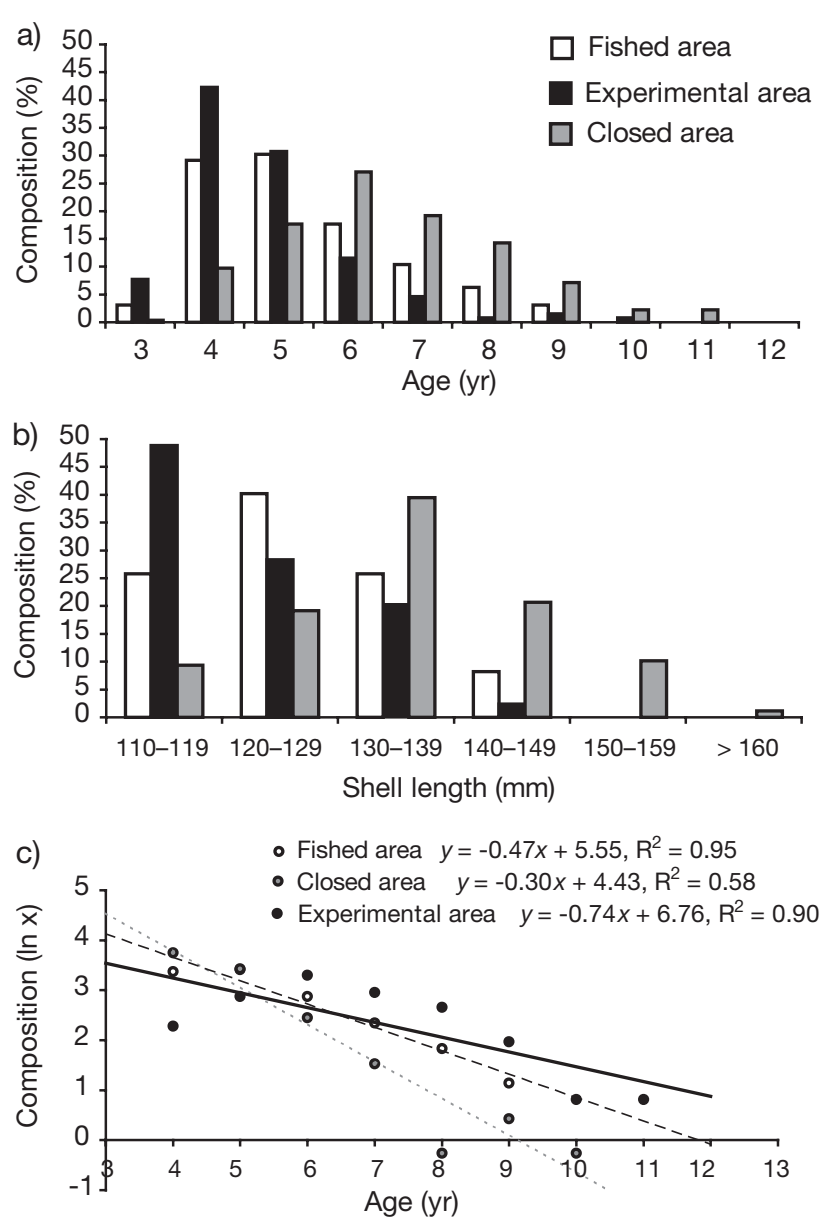

Fig. 7. Pecten maximus. Comparison of population structure and mortality estimates from the fished, experimental and closed areas in 2000 (scallops $\geq 110 \mathrm{~mm}$ only). All scallops collected by scallop dredges. (a) Age composition: fished area $\mathrm{n}=97$, experimental area $\mathrm{n}=130$, closed area $\mathrm{n}=270$; (b) Length composition: fished area $\mathrm{n}=97$, experimental area $\mathrm{n}=127$, closed area $\mathrm{n}=270$; (c) catch curve analysis (total mortality estimates) for the fished, experimental and closed area populations in 2000

was based on a single closed area-fished area comparison, so it could be argued that these results are only valid for our study site. However, the accumulation of results from similar studies is increasing our understanding of how marine populations and communities function in the absence of fishing pressure.

One of the most obvious and notable results of this study was the difference between scallop density in the closed and fished areas. Examination of the full time-series (1989 to 2003) of data on scallop densities in the closed area indicate that recovery of this scallop population accelerated as the duration of protection increased. Scallop densities in the fished area also increased over this time period, but not nearly to the extent observed in the closed area. This correlation may be because scallop populations in the 2 areas are not entirely independent. Given their close proximity, there is a real possibility of larval export and/or dispersal of scallops from the closed area to the fished area (see below), but this only makes our observations on the effects of protection more conservative. Several recent studies (Jennings 2000, Halpern \& Warner 2002) have emphasised the importance of examining recovery time when assessing the success of marine reserve protection. In contrast to the dramatic and rapid recovery of protected populations of Placopecten magellanicus on Georges Bank (Murawski et al. 2000), $P$. maximus populations in the Isle of Man closed area were slow to respond to protection. In the first few years of the study, illegal fishing may have contributed to this pattern (authors' pers. obs). The rapid rise in densities from the mid-1990s onwards, on the other hand, was probably related to patterns of recruitment. During this period, the scallop fishing grounds around the south and west of the Isle of Man received above average recruitment in several years, and during the 1998/99 fishing season, commercial catch rates in this area reached a 20 yr high (Beukers-Stewart et al. 2003). Recruitment into the closed area may have been even more successful due to the presence of high densities of hydroids, an important settlement substrate for pectinid larvae (Bradshaw et al. 2003). Yield-perrecruit models developed for $P$. magellanicus by Hart (2003) also demonstrate that closed area protection is most effective when timed to utilise unusually large year-classes. Long-term ( $>10 \mathrm{yr}$ ) studies of closed area protection such as ours are rare (Russ 2002), but (Russ \& Alcala 2004) have also recently shown that longterm protection is required for full recovery of predatory reef fish populations.

Between 2000 and 2003, differences in scallop density between the closed and fished areas reached their most extreme level. This period was also notable for dramatic fluctuations in scallop density in the closed

Table 8. Pecten maximus. Kolmogorov-Smirnov (K-S) 2 sample tests comparing population structure in the fished area $(n=97)$, experimental area $(n=127)$ and closed area $(n=270)$ in May/June 2000. (a) Age structure; (b) size structure. *Significant result

\begin{tabular}{|lcc|}
\hline Comparison & K-S $Z$ & $\mathrm{p}$ \\
\hline (a) & & \\
Fished vs. experimental & 1.29 & 0.07 \\
Fished vs. closed & 2.87 & $<0.01^{*}$ \\
Experimental vs. closed & 4.78 & $<0.01^{*}$ \\
(b) & & \\
Fished vs. experimental & 1.75 & $<0.01^{*}$ \\
Fished vs. closed & 3.37 & $<0.01^{*}$ \\
Experimental vs. closed & 4.74 & $<0.01^{*}$ \\
\hline
\end{tabular}


area. Scallop densities in the closed area increased considerably between 2000 and 2001, dropped in 2002 and then increased again in 2003. These observations may be partly explained by recruitment variation. For example, in 2001 a high proportion (approximately $35 \%$ or 7.22 scallops $/ 100 \mathrm{~m}^{2}$ ) of the scallops collected from the closed area were juveniles ( 1 and 2 yr old). In comparison, the combined density of 1 and 2 yr olds in the closed area was much lower in $2002\left(1.14 / 100 \mathrm{~m}^{2}\right)$ but then increased again (moderately) in 2003 (to 2.30/100 $\mathrm{m}^{2}$ ).

Another possibility is that the 2001 surveys of the closed area were biased towards areas where scallops occurred in high density. Due to logistical constraints, the 2001 dive survey concentrated on the inshore sector of the closed area, in water depths between 20 and $28 \mathrm{~m}$. Surveys of this same area in 2002 and 2003 tended to produce higher density estimates than further offshore (although this pattern was not statistically significant). This observation may be related to distance from the closed area boundary and therefore the effects of illegal fishing. A small and sporadic amount of illegal fishing has occurred within the closed area since it was first set up, but this has generally been concentrated in the deeper water close to the reserve boundaries (authors' pers. obs.) Several specific illegal incursions into the closed area in May 2002 (authors' pers. obs.) may also have contributed to the drop in scallop density between 2001 and 2002. In reality, recruitment levels, spatial coverage of the surveys, natural mortality and illegal fishing, probably all combined to generate the fluctuations in scallop density that we observed in the closed area between 2000 and 2003. Therefore, the 2001 estimates of scallop density in the closed area should be treated with some caution. In contrast, the 2002 and 2003 dive surveys were spread over wide areas of both the closed area and the fished area, and we are confident that our results represent a real difference between scallop densities in the fished and closed areas.

Comparison of the age/size structures of scallops in the closed area with those in the fished area, the resultant mortality estimates, and the results of the dredging experiment, all further illustrate the effects of fishing on populations of Pecten maximus. This pattern is not surprising, given the intensity of the scallop fishery around the Isle of Man. Recent estimates of the seasonal exploitation rate of the $P$. maximus population on the Bradda Inshore fishing ground range from approximately 41 to $50 \%$ ( $F=0.53$ to 0.69 ) (Brand \& Murphy 1992, Beukers-Stewart et al. 2003). If our estimate of total mortality for the closed area (0.22) is taken to represent natural mortality, and this value is subtracted from the estimate of total mortality for the fished area (0.76), a similar estimate for fishing mortality is pro- duced $(F=0.54)$. Most $P$. maximus on the Bradda Inshore ground do not obtain the minimum legal size of $110 \mathrm{~mm}$ SL until they are between 3 and 4 yr old (Allison 1994, this study), but we observed few individuals (approximately $5 \%$ of the population) more than $5 \mathrm{yr}$ old in the fished area. Fishing mortality therefore appears to largely remove each recruiting year-class within 3 yr. In comparison, scallops older than 5 yr made up more than $40 \%$ of the population in the closed area. However, scallops more than $10 \mathrm{yr}$ old were still relatively uncommon in the closed area, making up approximately $10 \%$ of the samples. In the first year of the Isle of Man scallop fishery (1937), scallops of $10 \mathrm{yr}$ or older accounted for over $55 \%$ of catches on the Bradda Inshore fishing ground (Tang 1941). This difference is probably because there were very few scallops in the closed area when it was set up in 1989 (14 yr prior to our last sample), and the population was initially slow to recover. However, our results do indicate that long-term protection from fishing is allowing the $P$. maximus population in the closed area to gradually shift back towards its original age/size structure (see also Bradshaw et al. 2001, Russ \& Alcala 2004).

The dramatic differences between the closed and fished areas in terms of both exploitable and reproductive biomass of scallops were perhaps the most significant results of this study. These patterns suggest that the closed population has the potential to strongly benefit the local fishery through larval export. For example, the reproductive output of Pecten maximus in the closed area in 2003 was likely to have been at least equivalent to that from an area of the fishing ground 12 times larger. However, the real difference was probably much greater. Since fertilization of scallop eggs is external, success is highly dependent upon the proximity of spawning individuals (Orensanz et al. 1991). The high density of scallops in the closed area (relative to the fished area) should therefore have enhanced fertilization success and reproductive output even further (Claereboudt 1999). Indeed, the very low density of scallops recently observed on fishing grounds around the Isle of Man at the end of each season (approximately 1/100 $\mathrm{m}^{2}$ ) has raised concerns about the possibility of recruitment failure in the fishery (Beukers-Stewart et. al. 2003). Pockets of high densities of large, old scallops (such as occurs in the closed area) may be crucial for ensuring the sustainability of this fishery.

Several trends suggest that the closed area examined in this study may have actually enhanced the surrounding scallop populations through larval export. Recruitment indices (the density of 2 yr old scallops) have increased significantly on 2 of the 3 fishing grounds surrounding the closed area during the period 
of closure, but not on any of the other 5 fishing grounds sampled (Beukers-Stewart et al. 2003, 2004). Commercial catch per unit effort (CPUE) has also increased significantly on all 6 fishing grounds off the west coast of the Isle of Man (i.e. nearest to the closed area) during the same time, but on only 1 of 4 east coast fishing grounds (and to a lesser extent on that ground) (Beukers-Stewart et al. 2003, 2004). This may be because Pecten maximus populations on the east and west coasts of the Isle of Man are reproductively isolated to a certain extent (Allison 1993, Heipel et al. 1998). Of course these patterns will have been at least partially driven by other factors such as variation in environmental conditions (e.g. Wolff 1987) and postsettlement survival (Beukers-Stewart et. al. 2003), so these data are only suggestive. It has been stated that providing definitive evidence for larval export from marine reserves may be almost impossible (Russ 2002), but circumstantial evidence, such as from this study, is continuing to build (Gell \& Roberts 2003). Improving knowledge of behaviour, dispersal and survival of larvae (i.e. via the use of genetic markers; Gilg \& Hilbish 2003) holds the key to substantiating such potential benefits of marine reserves.

Another possible explanation for the observed increases in scallop density in the fished area is that there was movement of scallops (spillover) from the closed to fished area. Analysis of the spatial distribution of scallops in the fished area did not provide any support for this hypothesis. In fact, scallop densities tended to be higher further away from the closed area boundary (but the data were highly variable). The generally sedentary nature of Pecten maximus (Howell \& Fraser 1984) also suggests that spillover would be unlikely. However, over the last 3 fishing seasons (2002 to 2004), local fishermen have expended an inordinate amount of effort fishing along the western boundary of the closed area (which was too deep for dive surveys), due to a perceived improvement in catch rates (authors' pers. obs). This anecdotal data is certainly suggestive of spillover, the validity of which could be tested via a suitably designed tagging study (Rowe 2001).

Along with the direct benefits of closed area protection mentioned above, there was also evidence of indirect benefits. Firstly, our data suggest that indirect fishing mortality was at least partly responsible for the loss of juvenile scallops from the fished area. Indirect fishing mortality (mortality of scallops discarded or damaged but not removed by fishing) has been identified as a major problem in other scallop fisheries (Naidu 1988, McLoughlin et al. 1991, Myers et al. 2000). Over both periods when the abundance of $2 \mathrm{yr}$ old scallops was monitored, loss rates were higher in the fished area than in the closed area. These scallops would have remained below legal size during each sampling period, so loss would not have been due to direct fishing mortality. Between 2001 and 2002, predator densities were not significantly different in the 2 areas, so this is unlikely to have been a contributing factor either. Between 2002 and 2003, the picture was less clear, however. While the density of 2 yr old scallops was similar in both areas in 2002, by 2003 the density of these scallops had doubled in the closed area but declined by $35 \%$ in the fished area. Due to the sedentary nature of Pecten maximus (see above), this increase in the closed area is unlikely to have been caused by immigration, so it was probably due to the improved detection of this year-class by divers after the scallops had grown to a larger size. Therefore our estimates of the density and mortality of juvenile scallops (ones less than 3 yr old) may only be relative. Although this still indicates that loss of juvenile scallops was again higher in the fished area, the density of the starfish Asterias rubens (a major predator of $P$. maximus) was significantly higher in the fished area in 2003. The influence of indirect fishing mortality on the 2002/2003 results is therefore unknown.

Several previous studies and observations of the Isle of Man scallop fishery suggest mechanisms by which indirect fishing mortality may be occurring (Jenkins et al. 2001, 2004, Jenkins \& Brand 2001). Although there is a minimum legal size of $110 \mathrm{~mm} \mathrm{SL}$, a high number of scallops below this size are commonly retained by the dredges to be subsequently discarded (up to $70 \%$ of the total scallop catch on some grounds; authors' unpubl. data). Up to $20 \%$ of these scallops suffer a combination of lethal and sub-lethal shell damage (S. R. Jenkins et al. unpubl. data). Similar damage levels are also found in scallops that encounter the dredges but are left on the seabed (Jenkins et al. 2001). Given an overall dredge efficiency of approximately $20 \%$, these account for 4 times as many scallops as are landed. In addition, even scallops that encounter the dredges without damage to their shells suffer an impaired swimming escape response (Jenkins \& Brand 2001). These damaged and/or stressed scallops are known to be more vulnerable and attractive to predators than undisturbed individuals (Jenkins et al. 2004).

Differences between the mean size-at-age of juvenile scallops in the closed and fished areas could also have been due to fishing disturbance. In both 2002 and 2003 mean size of 1 yr old scallops was actually slightly higher in the fished area than the closed area (significantly so in 2003), but this pattern reversed between 1 and 3 yr old. One year old scallops are rarely retained by the scallop dredges used around the Isle of Man, but dredge efficiency increases substantially for $2 \mathrm{yr}$ old scallops before reaching full efficiency for 3 yr olds (B. D. Beukers-Stewart et al. unpubl. data). Dredging is 
therefore likely to have a minimal effect on 1 yr old scallops, but an increasing effect on older/larger individuals. The 2 and 3 yr old scallops in the fished area may therefore have grown more slowly because they were expending energy recovering from dredgeinduced stress and/or damage. Given the similarity of growth patterns over the first year, the close proximity of the 2 sample sites, and their similar water depths and substrate, environmental conditions do not appear to explain these differences (see Orensanz et al. 1991). The reduction in size-at-age of 2 and 3 yr old scallops in the fished area may have caused the reduced size of older scallops. This reduction in mean size would, in turn, have reduced the potential reproductive output from the fished population (see above). The use of closed areas to protect scallops during the juvenile phase may therefore increase their survival and growth, assisting in the overall recovery of these populations.

Several authors have advocated the merits of using rotational closed areas for managing invertebrate fisheries (Botsford et al. 1993, Myers et al. 2000, Zhang \& Campbell 2002, Hart 2003). However, based on our results, the Isle of Man fishery for Pecten maximus would be better served by a network of permanent (rather than rotational) closed areas. The scallop population we studied required more than $10 \mathrm{yr}$ of protection before significant differences were observed between densities in the closed and fished areas. Although this was partly the consequence of illegal fishing early on (see above), and several years of poor recruitment (Beukers-Stewart et al. 2003), very long periods ( 5 to $10 \mathrm{yr}$ ) appear to be needed to build up stock levels. In addition, if pockets of high spawning stock biomass are needed to ensure regular recruitment (as our data suggest), then opening up these areas would quickly remove the largest and most reproductively active individuals, dramatically reducing overall reproductive output.

The process of establishing a network of permanent closed areas would need to be carefully assessed on a cost/benefit basis. Closing areas of a fishery will initially reduce the resources available to fishermen. Fishermen therefore need to be involved in the decision-making process and may require compensation or financial assistance in the short-term. Support from the local fishing community is likely to be crucial for ensuring that closed area boundaries are effectively enforced. For example, promoting the potential fishery benefits of the Isle of Man closed area among local fishermen has lead to a dramatic drop in illegal fishing in the area in recent years (authors' pers. obs.). It has also been argued that closed area protection may simply divert fishing effort to other areas or species, causing irrevocable damage (Horwood et al. 1998,
Horwood 2000). This possibility needs to be considered and incorporated into management plans. For closed area management to be judged as successful, the simple rule of thumb is that the fisheries in question become more productive than they were under previous management schemes (Gell \& Roberts 2003).

In summary, this study joins a growing number indicating that the use of closed areas offers a range of benefits over more traditional methods of managing fisheries. Fisheries for scallops appear to be particularly suitable for this type of management. The challenge now is to provide stronger empirical evidence for larval export and spillover from closed areas, and in the process gain the support of both the industry and fisheries managers.

Acknowledgements. This study was funded by the Department of Agriculture, Fisheries and Forestry of the Isle of Man Government and by the UK Ministry of Agriculture, Fisheries and Food (grant number CSA 4142). Many thanks to the boat crews of the RV 'Sula' and RV 'Roagan' and to the numerous people who helped collect the dive and dredge survey data over the years. Special thanks also to C. Bradshaw and L. O. Veale for many useful discussions and for allowing us to participate in the experimental dredging programme. S. R. Jenkins provided the idea to use DGPS to measure dive surveys. Drafts of this manuscript were considerably improved by comments from F. R. Gell, C. H. Peterson and 2 anonymous reviewers.

\section{LITERATURE CITED}

Allison EH, Wilson UAW, Brand AR (1994) Age determination and the first growth ring in north Irish Sea populations of the scallop, Pecten maximus (L.). J Molluscan Stud 60:91-95

Allison GW, Lubchenco J, Carr MH (1998) Marine reserves are necessary but not sufficient for marine conservation. Ecol Appl 8:S79-S92

Ansell AD, Dao JC, Mason J (1991) Three European scallops: Pecten maximus, Chlamys (Aequipecten) opercularis and C. (Chlamys) varia. In: Shumway SE (ed) Scallops: biology, ecology and aquaculture. Elsevier, Amsterdam, p 715-751

Beukers-Stewart BD, Jenkins SR, Brand AR (2001) The efficiency and selectivity of spring-toothed scallop dredges: a comparison of direct and indirect methods of assessment. J Shellfish Res 20:121-126

Beukers-Stewart BD, Mosley MWJ, Brand AR (2003) Population dynamics and predictions in the Isle of Man fishery for the great scallop, Pecten maximus (L.). ICES J Mar Sci 60:223-241

Beukers-Stewart BD, Vause BJ, Mosley MWJ, Brand AR (2004) Evidence for larval export of scallops from a small closed area off the Isle of Man ICES Annual Science Conference. ICES, Vigo, Spain. ICES CM 2004/Y:17

Beverton RJH, Holt SJ (1957) On the dynamics of exploited fish populations. Fishery Investigations Series II. UK Ministry of Agriculture, Fisheries and Food, London

Botsford LW, Quinn JF, Wing SR, Brittnacher JG (1993) Rotating spatial harvest of a benthic invertebrate, the red sea urchin, Strongylocentrotus franciscanus. In: Kruse G, Eggers DM, Marasco RJ, Pautzke C, Quinn TJ II (eds) Proceedings of the International Symposium on Management 
Strategies for Exploited Fish Populations. University of Alaska, Fairbanks, AK, p 409-428

Bradshaw C, Veale LO, Hill AS, Brand AR (2001) The effect of scallop dredging on Irish Sea benthos: experiments using a closed area. Hydrobiology 465:129-138

Bradshaw C, Collins P, Brand AR (2003) To what extent does upright sessile epifauna affect benthic biodiversity and community composition? Mar Biol 143:783-791

Brand AR (1991) Scallop ecology: distributions and behaviour. In: Shumway SE (ed) Scallops: biology, ecology and aquaculture. Elsevier, Amsterdam, p 517-584

Brand AR, Murphy EJ (1992) A tagging study of north Irish Sea scallop (Pecten maximus) populations: comparisons of an inshore and an offshore fishing ground. J Med Appl Malacol 4:153-164

Brand AR, Paul JD, Hoogesteger JN (1980) Spat settlement of the scallops Chlamys opercularis (L.) and Pecten maximus (L.) on artificial collectors. J Mar Biol Assoc UK 60: 379-390

Brand AR, Beukers-Stewart BD, Vause BJ, Mosley MWJ (2004) Shellfish Research Report to the Isle of Man Government, Department of Agriculture, Fisheries and Forestry. Port Erin Marine Laboratory, University of Liverpool

Claereboudt C (1999) Fertilization success in spatially distributed populations of benthic free-spawners: a simulation model. Ecol Model 121:221-233

Cortes E, Parsons GR (1996) Comparative demography of two populations of the bonnethead shark (Sphyrna tiburo). Can J Fish Aquat Sci 53:709-718

Dayton PK, Sala E, Tegner MJ, Thrush S (2000) Marine reserves: parks, baselines, and fishery enhancement. Bull Mar Sci 66:617-634

Gaines SD, Gaylord B, Largier JL (2003) Avoiding current oversights in marine reserve design. Ecol Appl 13: S32-S46

Gell FR, Roberts CM (2003) Benefits beyond boundaries: the fishery effects of marine reserves. Trends Ecol Evol 18: 448-455

Gilg MR, Hilbish TJ (2003) The geography of marine larval dispersal: coupling genetics with fine-scale physical oceanography. Ecology 84:2989-2998

Grantham BA, Eckert GL, Shanks AL (2003) Dispersal potential of marine invertebrates in diverse habitats. Ecol Appl 13:S108-S116

Halpern BS (2003) The impact of marine reserves: Do reserves work and does reserve size matter? Ecol Appl 13:S117-S137

Halpern BS, Warner RR (2002) Marine reserves have rapid and lasting effects. Ecol Lett 5:361-366

Hart DR (2003) Yield- and biomass-per-recruit analysis for rotational fisheries, with an application to the Atlantic sea scallop (Placopecten magellanicus). Fish Bull 101:44-57

Heipel DA, Bishop JDD, Brand AR, Thorpe JP (1998) Population genetic differentiation of the great scallop Pecten maximus in western Britian investigated by randomly amplified polymorphic DNA. Mar Ecol Prog Ser 162:163-171

Horwood JW (2000) No-take zones: a management context. In: Kaiser MJ, de Groot SJ (eds) Effects of fishing on nontarget species and habitats. Gray Publishing, Tunbridge Wells, p 302-311

Horwood JW, Nichols JH, Milligan S (1998) Evaluation of closed areas for fish stock conservation. J Appl Ecol 35:893-903

Howell TRW, Fraser DI (1984) Observations on the dispersal and mortality of the scallop, Pecten maximus (L.). ICES CM 1984/K
Jenkins SR, Brand AR (2001) The effect of dredge capture on the escape response of the great scallop, Pecten maximus (L.): implications for the survival of undersized discards. J Exp Mar Biol Ecol 266:33-50

Jenkins SR, Beukers-Stewart BD, Brand AR (2001) The impact of scallop dredging on benthic megafauna: a comparison of damage levels in captured and non-captured organisms. Mar Ecol Prog Ser 215:297-301

Jenkins SR, Mullen C, Brand AR (2004) Predator and scavenger aggregation to discarded by-catch from dredge fisheries: importance of damage level. J Sea Res 51:69-76

Jennings S (2000) Patterns and prediction of population recovery in marine reserves. Rev Fish Biol Fish 10: 209-231

Jennings S, Kaiser MJ (1998) The effects of fishing on marine ecosystems. Adv Mar Biol, 34:201-352

Kimura DK (1980) Likelihood methods for the von Bertalanffy growth curve. Fish Bull 77:765-776

Lizaso JLS, Goni R, Renones O, Charton G, Galzin R, Bayle JT, Jerez PS, Ruzafa AP, Ramos AA (2000) Density dependence in marine protected populations: a review. Environ Conserv 27:144-158

Marelli DC, Arnold WS, Bray C (1999) Levels of recruitment and adult abundance in a collapsed population of bay scallops (Argopecten irradians) in Florida. J Shellfish Res 18:393-399

McClanahan TR, Mangi S (2000) Spillover of exploitable fishes from a marine park and its effect on the adjacent fishery. Ecol Appl 10:1792-1805

McLoughlin RJ, Young PC, Martin RB, Parslow J (1991) The Australian scallop dredge: estimates of catching efficiency and associated indirect fishing mortality. Fish Res 11:1-24

Mosquera I, Cote IM, Jennings S, Reynolds JD (2000) Conservation benefits of marine reserves for fish populations. Anim Conserv 3:321-332

Murawski SA, Brown R, Lai HL, Rago PJ, Hendrickson L (2000) Large-scale closed areas as a fishery-management tool in temperate marine systems: the Georges Bank experience. Bull Mar Sci 66:775-798

Murray SN, Ambrose RF, Bohnsack JA, Botsford LW and 15 others (1999) No-take reserve networks: sustaining fishery populations and marine ecosystems. Fisheries 24:11-25

Myers RA, Fuller SD, Kehler DG (2000) A fisheries management strategy robust to ignorance: rotational harvest in the presence of indirect fishing mortality. Can J Fish Aquat Sci 57:2357-2362

Naidu KS (1988) Estimating mortality rates in the Iceland scallop, Chlamys islandica (O.F. Muller). J Shellfish Res 7:61-71

Orensanz JM, Parma AM, Iribarne OO (1991) Population dynamics and management of natural stocks. In: Shumway SE (ed) Scallops: biology, ecology and aquaculture. Elsevier, Amsterdam, p 625-713

Pauly D, Christensen V, Guenette S, Pitcher TJ, Sumaila UR, Walters CJ, Watson R, Zeller D (2002) Towards sustainability in world fisheries. Nature 418:689-695

Peterson CH, Summerson HC (1992) Basin-scale coherence of population dynamics of an exploited marine invertebrate, the bay scallop: implications of recruitment limitation. Mar Ecol Prog Ser 90:257-272

Roberts CM, Bohnsack JA, Gell F, Hawkins JP, Goodridge R (2001) Effects of marine reserves on adjacent fisheries. Science 294:1920-1923

Rowe S (2001) Movement and harvesting mortality of American lobsters (Homarus americanus) tagged inside and outside no-take reserves in Bonavista Bay, Newfoundland. Can J Fish Aquat Sci 58:1336-1346 
Russ GR (2002) Yet another review of marine reserves as reef fishery management tools. In: Sale PF (ed) Coral reef fishes: dynamics and diversity in a complex ecosystem. Academic Press, San Diego, CA, p 421-443

Russ GR, Alcala AC (2004) Marine reserves: long-term protection is required for full recovery of predatory fish populations. Oecologia 138:622-627

Stokesbury KDE (2002) Estimation of sea scallop abundance in closed areas of Georges Bank, USA. Trans Am Fish Soc 131:1081-1092

Stokesbury KDE, Harris BP, Marino MC, Nogueira JI (2004) Estimation of sea scallop abundance using a video survey in off-shore US waters. J Shellfish Res 23:33-40

Tang SF (1941) The breeding of the scallop (Pecten maximus (L.)) with a note on growth rate. Proc Trans Liverpool Biol Soc 54:9-28

Thrush SF, Dayton PK (2002) Disturbance to marine benthic habitats by trawling and dredging: implications for marine biodiversity. Annu Rev Ecol Syst 33:449-473

Tuya FC, Soboil ML, Kido J (2000) An assessment of the effectiveness of marine protected areas in the San Juan Islands, Washington, USA. ICES J Mar Sci 57:1218-1226

Editorial responsibility: Charles Peterson (Contributing Editor), Morehead City, North Carolina, USA
Underwood AJ (1981) Techniques of analysis of variance in experimental marine biology and ecology. Oceanogr Mar Biol Annu Rev 19:513-605

Veale LO, Hill AS, Hawkins SJ, Brand AR (2000) Effects of long-term physical disturbance by commercial scallop fishing on subtidal epifaunal assemblages and habitats. Mar Biol 137:325-337

Whittington MW (1993) Scallop aquaculture in Manx waters: spat collection and the role of predation in seabed cultivation. $\mathrm{PhD}$ thesis, University of Liverpool

Wilson UAW (1994) The potential for cultivation and restocking of Pecten maximus (L.) and Aequipecten (Chlamys) opercularis (L.) on Manx inshore fishing grounds. PhD thesis, University of Liverpool

Wilson UAW, Brand AR (1994) Nowhere to hide? Predator impact on seeded scallops. Can Tech Rep Fish Aquat Sci 2:118

Wolff M (1987) Population dynamics of the Peruvian scallop Argopecten purpuratus during the El Niño phenomenon of 1983. Can J Fish Aquat Sci 44:1684-1691

Zhang Z, Campbell A (2002) Application of a stochastic spawning stock biomass per recruit model for the horse clam fishery in British Columbia. Fish Res 57:9-23

Submitted: May 19, 2004; Accepted: February 17, 2005 Proofs received from author(s): July 27, 2005 